NBER WORKING PAPERS SERIES

INTERNATIONAL ACCOUNTING DIVERSITY: DOES IT IMPACT MARKET PARTICIPANTS?

Frederick D.S. Choi

Richard M. Levich

Working Paper No. 3590

\author{
NATIONAL BUREAU OF ECONOMIC RESEARCH \\ 1050 Massachusetts Avenue \\ Cambridge, MA 02138 \\ January 1991
}

This manuscript is based on a larger study, Frederick choi and Richard Levich, The capital Market Effects of International Accounting Diversity, Homewood, Illinois: Dow Jones-Irwin, 1990 . The original study was funded by a grant from Arthur Anderson \& Co. and Salomon Brothers, Inc. The analysis and conclusions in this paper are those of the authors and do not reflect the views of any of the participating institutions. This paper is part of NBER's research program in International studies. Any opinions expressed are those of the authors and not those of the National Bureau of Economic Research. 
NBER Working Paper \#3590

January 1991

\title{
INTERNATIONAL ACCOUNTING DIVERSITY: DOES IT IMPACT MARKET PARTICIPANTS?
}

\begin{abstract}
While many indicators point to the globalization of capital markets, one barrier may persist -- International Accounting Diversity. Even though coordination of many national policies is gaining favor, the measurement and disclosure principles that underlie financial statements remain largely a nationalistic affair.

In this paper, we analyze the channels through which accounting diversity affects financial statements. Accounting differences may affect cash flows and lead to a direct affect on valuation. Accounting differences may also affect balance sheet items and measures of capital adequacy or credit worthiness that indirectly affect managerial decisions and firm valuation.

In a survey of participants in the international capital market, we find that accounting diversity is a problem that affects the capital market decisions of roughly one-half of the participants in our study. Thus, we cannot rule out the possibility that international accounting diversity is a barrier whose presence may affect the pricing of securities and the composition of international portfolios. On the other hand, roughly one-half of the participants in this study found what they described as effective ways of coping with diversity. These coping mechanisms may be useful for other investors and issuers in making their capital market decisions.

Frederick D.S. Choi New York University Stern School of Business 100 Trinity Place New York, NY 10006

Richard M. Levich New York University Stern School of Business 100 Trinity Place New York, NY 10006
\end{abstract}




\section{Introduction}

When asked to comment on the themes that will characterize capital markets in the 1990s, portfolio managers and security analysts now routinely cite 'globalization of markete' as a major trend. There is plenty of hard evidence to support their forecast. In 1988, the United States accounted for less than $30 \%$ of world GNP, down from roughly $50 \%$ in 1960.1 in 1989. the market capitalization of U.S. securities markets was nearly 18 trillion or $39 \%$ of the world total, whereas in 1970, the United States accounted for more than two-thirds of world market capitalization. ${ }^{2}$ U.S. gross purchases and sales of foreign stocks reached $\$ 140$ billion in 1988, a nine-fold increase over 1982, while foreign gross purchases and sales of U.S. stocks exceeded $\$ 380$ billion, a five-fold increase over the same time period. ${ }^{3}$ Recent regulatory changes in the United States (Rule 144A) and ongoing regulatory changes in the European Commity should further allow for linkages between national markets."

The relative shrinkage of the U.S. economy suggests that passive U.S. investors ought to hold a larger fraction of non-U.S. securities to achieve well-diversified portfolios. And active U.S. investors have been attracted by higher rates of growth outside the United States, as well as special situations such as privatization of foreign firms (e.g. British Air and British Telecon), growth opportunities associated with Europe 1992, and the developing marketoriented economies of Eastern Europe and Southeast Asia. The surge in specialized country funds and international mutual funds in 1989 illustrates these trends.

While the stage seems to be set for globalization of capital markets, one barrier may persist - International Accounting Diversity. ${ }^{5}$ Even though coordination of many national

1 Based on 113 countries in 1988 and 93 countries in 1960 reporting in the International Financial Statistics Yearbook (1989).

2 Data for the United States in 1988 reflects roughly $\$ 3$ trillion in equities and $\$ 5$ trillion in bonds. See International Herald Tribune. September 8-9, 1990. Data for 1970 are from Morgan Stanley Capital International. In part, this trend reflects the tremendous growth in emerging markets documented by the World Bank (1989). However, the growth of some foreign markets may be exaggerated as corporate cross-holding leads to double counting. See French and Poterba (1989).

3 U.S. Goverment Accounting Office, (1989, pp.9-10).

4 Rule 144A, adopted on April 19, 1990, intends to expand the ability of foreign firms to place securities with large institutional investors in the United states by allowing the resale of these securities to other large investors. See Gurwitz (1989).

5 other barriers to international investment that have been analyzed include taxation (Black, 1974), and ownership restrictions (Stapleton and subrahmanyam, 1977 and Eun and Janakiramanen, 1986). 
policies - trade policy, fiscal and monetary policy, and banking regulation - are gaining favor, the measurement and disclosure principles that underlie financial statement reports have remained largely ationalistic affair. When accounting reporta rotain a nationallatic character, apparent differences in financial measures of enterprise risk and return characteristics could be due as much to differences in account ing measurement rules as they are to real differences in the attributes being measured. In the globalized enviroment of the 1990 s, when a reader from one country examines financial statements from a firm in another country, will the reader be able to understand (a) the impact of accounting measurement differences, (b) the impact of economic, cultural and institutional differences, and (c) the remaining real economic attributes of the firm being measured? Bear in mind that this difficult problem is compounded, in practice, by the fact that certain accounting data are not disclosed in some countries. Even where disclosures are similar, differences in auditing standards may offect the reader's confidence in reported figures. 6

The purpose of this paper is three-fold. First, we briefly outline the channels though which accounting diversity affects financial statements, and in turn affects institutional investors and corporate issuers. Second, we report the findings of a study of participants in the international capital markets that examines whether international accounting diversity affects capital market decisions and how these participants cope with accounting differences. Third, we sumarize the implications of our study for institutional investors and corporate issuers.

our main finding is that international accounting diversity is a problem that affects the capital market decisions of roughly one-half of the participants in our study. Thus we cannot rule out the possibility that international accounting diversity is a barrier whose presence may affect the pricing of securities and the composition of international portfolios. On the other hand, roughly one-half of the participants in this study found what they described as effective ways of coping with diversity. These coping mechanisms may be useful for other investors and issuers in making their capital market decisions.

6 Branson and Jaffe (1989) analyze the implications of the quality of information on international capital mobility and welfare. 


\section{Investors, Issuers, and Accounting Diversity}

In this section, we briefly describe several channels through which accounting diversity could impact the financial statements that are presented to international investora. Accounting diversity embraces differences in accounting principles, disclosure practices and auditing standards. Our focus here is on the first two components of accounting diversity. ${ }^{7}$

Differences abound in accounting principles across countries. 8 Accounting rules may affect the value of the firm via several channels. To begin, national accounting rules are typically well-integrated with national codes for taxation. Accounting rules for taxation that pertain to the recognition of income and expenses, non-cash items such as depreciation and reserving, and dozens of other rules come together to set the definition of corporate income and, in turn, corporate taxes. As taxes are real cash flows, accounting diversity may have a direct affect on firm valuation. Second, complementing their impact on tax payments, account ing rules may also impact the figures used by managers for decision making as well as the figures pertaining to managerial performance evaluation (e.g. compensation). This may have an impact on managerial decisions, and in turn, corporate cash flows. Third, accounting rules affect the magnitudes of the numbers that are released externally for shareholders and financial analysts. In addition, rules on disclosure may alter the categories of information that are released. Variation in this external information base may directly affect analysts' estimates of the market value of the firm .- either by affecting the expected value of key variables or the uncertainty surrounding these estimates. Or the effect of variation in externally reported information on market value may be indirect, through an effect on the firm's credit rating or credit capacity.

Account ing diversity, therefore, holds the possibility of leading to a real economic difference by changing managerial decisions, corporate cash flows, or analysts' evaluations of the firm. But accounting diversity may have only a nominal impact (i.e. a change in accounting numbers but not a change in market values) if the account ing rules affect only noncash flow items, or do not affect the variables that managers use for decision making, or do not affect evaluations of the firm by external analysts.

7 Most respondents in our survey felt that differences in auditing practices were part of accounting diversity, but that coping was straightforward. Investors in our study would only consider firms with statements audited by large, well-regarded accounting firms.

8 See Table 4 of Choi and Levich (1990) for a comparison of 30 accounting principles across 8 countries. 
The connections between accounting diversity and the firm's economic environent are summerized in figure 1. If we consider the case of two firms that are similarly situated in economic terms, then clearly it would be logical for those firms to follow simllar accounting practices [Box A]. And if they did, then the accounting statements of the two firms could be used for comparative analysis.

If these two similarly situated firms were permitted to adopt two dissimilar accounting treatments [Box $\mathrm{C}$ ], then the firms would be made to appear dissimilar. This hypothetical case could represent a real effect if, for example, one firm used aggressive accounting techniques to gain a real cash-flow odvantage. Since the two firms are similarly situated, a variation in accounting treatments would pose an unacceptable competitive result. on the other hand, this hypothetical case could simply represent a nominal effect that financial analysts would "see through" after spending some additional time and effort. ${ }^{9}$ In either case, the combination illustrated by Box $C$ is an inappropriate choice and the accounting reports of the firms would not be (by themselves) suitable for comparative analysis.

The more interesting cases involve firms that are dissimilar in a real economic sense. It is sometimes argued that the case for accounting harmony in the presence of diverse economic situations [BOX B] is that meaningful inter-firm comparisons are then possible. For example, an airline that depreciates its aircraft over five years (because these aircraft make thousands of take-offs and landings per year) is not similarly situated to an airline that flies longhaul routes and depreciates their aircraft over 10 years. Use of the same accounting rule (in this case, straight-line depreciation) allows this economic difference to be highlighted.

However, suppose that the dissimilarity between the two firms pertains to the legal definition of income, or the rules available for computing taxes, or the cultural or accounting variables that influence managerial performance measures and compensation. Then the adoption of similar accounting treatments will only obscure the dissimilarities between the two firms. As a result, when the economic situation of firms is dissimilar, the adoption of similar accounting treatments [BoX B] may or may not be an appropriate and logical response.

In cases where our two hypothetical firms are in the same industry and the same tax laws and business customs apply, then it seems clear that the firms ought to use similar

9 The empirical evidence in Ball (1972) strongly suggests that share prices are set as though analysts were able to see through nominal accounting changes. 
accounting practices, if only to maintain a level competitive playing field. ${ }^{10}$ However, when the source of the dissimilarity relates to national tax rules, national industry practices or regulations, then as we have argued elsewhere (Choi and Levich, 1990), dissimflar accounting treatments may be necessary [Box D]. In this case, however, direct comparisons between firms may be difficult.

The treatment of goodwill offers a clear illustration of the potential impact of principles differences. Suppose that $f i r m A$ with a book value of $\$ 5$ billion is purchased for S6 billion by firm B. In the United States, firm 8 us would book the excess $\$ 1$ billion as an asset (goodwill) and amortize it over a period not to exceed 40 years. At the end of the amortization period, the book value of shareholder equity for firm $B_{\text {US }}$ will be lower by $\$ 1$ billion. As a result of higher amortization expense, Bus will report lower earnings. This might appear to put U.S. firms at a disadvantage. However, since amortization is a non-cash item, cash flows available from the acquisition of firm $A$ will be unaffected. ${ }^{11}$

In the United Kingdom, the excess $\$ 1$ billion associated with the purchase of Firm $A$ generally would be charged immediately against shareholder equity, leaving reported earnings, taxable earnings and income taxes for firm $B_{U K}$ unaffected by any amortization charges. However. the write-off of goodwill in the United Kingdom raises the debt to equity ratio for firm $B_{U K}$. Assuming that this change does not affect the firm's credit rating or cost of borrowed funds, the reported earnings of $\mathrm{firm}^{B_{U K}}$ would remain unaffected. ${ }^{12}$ if the capital markets (i.e. investors or rating agencies) respond to differences in reported earnings book values rather than to cash flows, then the accounting treatment of goodwill might give bidding firms from the United Kingdorm an advantage over firms from the United States. ${ }^{13}$

10 The new supervisory guidel ines for banking from the Bank for International settlements (BIS) are a good case in point. Now that policymakers have agreed to uniform guidelines for bank supervision (including capital adequacy measures, risk rating measures, etc.) uniform accounting seems to be natural outgrowth.

11 If amortization of goodwill applied to tax accounting as well, then Bus would experience lower taxable earnings and lower corporate income taxes -. providing a net improvement to real cash flows.

12 In an empirical study of U.K. firms in the 1982-1986 period, Russell, et al. (1989) conclude that firms with stronger balance sheets tend to write off larger amounts of acquired goodwill. These firms would incur a smaller impact on their credit ratings. This evidence is largely consistent with the positive accounting framework of Watts and Zimmerman (1986).

13 In the United Kingdom, the Account ing Standards Committee has proposed a change in the treatment of gooduill to bring U.K. practices into closer conformity with U.S. practices. However, this proposal has yet to be adopted. For more on the treatment of goodwill across countries, see U.S. Goverment Accounting office (1987). 
other differences in accounting principles can also lead to asymetric effects. For example, recognition of deferred taxes as a current expense item is permitted in the United states and the United Kingdom, but disallowed in Germany, Switzerland and Sweden. This accounting difference may exert an upward bias on earnings from the latter countries. Similerly, general purpose, or purely discretionary reserves are not allowed in the United States and the United Kingdom. However they are commonplace in Germany, Switzerland, Japan, and elsewhere. As over-reserving is popular, reported earnings from these countries may have a tendency to be "under-stated," except during periods of economic downturn when discretionary reserving is relaxed.

Differences in the disclosure of accounting data and accounting practices are also widespread. Frequency of reporting is perhaps the most basic difference. The United states is alone in requiring quarterly reports of its large publicly traded firms. Most of the rest of the world requires only semi-annual or annual reporting. As a result, comparison of first, second and third quarter reports between U.S. firms and other firms is ruled out. When likedated reports are available, U.S. firms will typically provide more segmental information -. the break-down of sales and profits across geographic regions and product lines -- than do foreign firms. U.S. firms may also be more forthconing about their off-balance sheet transactions, contingencies, and valuation procedures. On the other hand, foreign firms may disclose more about their accounting for tax authorities, if only because their external reports use the same procedures for recognizing incone, calculating depreciation, and so forth as is required by the tax authorities.

The final point reveals a critical difference between the United States and foreign countries. In the United states, there are accounting principles for external reporting (GAAP), accounting principles for the calculation of taxes (TAP), accounting for regulatory bodies (RAP) and perhaps accounting for managerial decision making. In other countries such as Germany, Italy, and Japan, accounting principles are said to be "tax-driven" as there is no distinction between TAP, RAP, and GAAP. If accounting rule changes would have immediate cash flow and tax implications, it is easy to understand why firms would resist conforming to some external standard. And, where firms come from a tradition of supplying only one "correct" accounting statement, it is easy to understand why they would resist preparing a second (potentially confusing) accounting statement even it had no cash flow implications.

our brief analysis of international accounting principle differences raises doubts as to whether meaningful cross-country comperisons are possible. Consider the case of a U.S. firm 
(Philip Morris) that might have been bidding for Pillsbury versus the U.K. firm (Grand Metropolitan) that finally acquired Pillsbury. The accounting and tax treatment that Grand Met enjoys as a U.K. firm is a non-traded asset. While one could restate the accounts of Grand Met as if it were a U.S. firm (Figure 1, box (B)) reporting according to U.S. GAAP and TAP, this would mislead readers from the fact that Grand Met is in fact a U.K. firm and able to pass along to shareholders whatever costs and benefits there are in the U.K. accounting and tax system.

The difficulty of comparative anolys is across firms within an international industry corresponds nicely to the "top-down" investment approach commonly employed by institutional investors. In this approach, investors first select an asset allocation across countries on the basis of macroeconomic variables. The choices of countries may be tempered by market size, liquidity, absence of capital controls, political risk and so forth. The result is a set of portfolio weights for countries rather than for industries. Given these allocations, investors are led to ask which are the best stocks within countries rather than which are the best within an industry but across countries. As a result, comparative analys is of firms across countries (with differing accounting principles) is discouraged.

\section{Motivation for the Study and Methodology}

While international accounting differences such as those mentioned above have been chronicled in the literature, little research has explored whether these differences matter in the sense that they affect the location of investing and issuing activity, the composition of international portfolios, or the prices of securities. Naturally, international accounting differences are "important" in the trivial sense that the reader must know whether he is about to read financial statements prepared according to U.S., French or Japanese accounting principles -. exactly as anyone must know whether a distance is expressed in miles or kilometers before making travel decisions. In the travelling example, we would expect that the choice of units of measurement has no impact on travel decisions. Can it also be said that the choice of accounting principles has no impact on capital market decisions?

The existing literature in accounting and financial markets contains several important themes. First, the seminal work of Ball and Brown (1968) concludes that accounting earnings data include relevant information that affects share prices. The Ball and Brown methodology has been applied in numerous related contexts and the results are consistent with the contention that earnings announcements (including those generated under U.K. GAAP, Australian 
GAAP, Swedish GAAP, and so forth) provide timely and relevant information to the market.

A second strand of research suggests that investors are not misled by changes in accounting rules. In the cases studied by 8 all (1972), firms that adopted accounting rule changes tended to display a pattern of lower returns relative to the market. One interpretation of these results is that these firms may have adopted accounting changes to improve the appearance of their reported accounting numbers. Capital markets apparently saw through these decisions, since share prices moved well in advance of the accounting changes. 14

Overall, previous research suggests that accounting information is meaningful for investors, and so knowledge of international accounting rules should be important. However, investors are known to rely also on non-accounting information that helps them to "see through" accounting changes and differences that are purely nominal. It is an empirical question whether international accounting differences have an impact on capital market decisions.

To approach this question, we undertook in-depth interviews with users and providers of international accounting statements. To arrive at a representative sample, we stratified the universe into several dimensions -- geographic location, user group and size. We sampled participants from Germany, Japan, Switzerland, United Kingdom and the United States. These are countries whose capital market institutions have a large stake in international investments, and in the case of Germany, Japan and Switzerland, whose accounting principles diverge quite significantly from international norms. Four primary user groups were identified -institutional investors, corporate issuers, investment underwriters, and market regulators. 15 The sample design resulted in $\mathbf{5 2}$ institutions distributed across various categories as shown in Table 1. The names of these institutions are listed in Appendix 1. Owing to the expense associated with the interview survey method (especially in an international context) our sample is not large. However, the sample was selected in large!; random fashion and, hence, our findings should be fairly representative.

14 A related area of research is how markets respond to non-trivial changes in account ing practices, in particular to increase above (or decrease below) a standard level of reporting. the evidence in Choi (1973) suggests that in the Eurobond market firms often precede their offering by an increase in the volume and quality of their financial disclosures, and these actions tend to lower the cost of funds. Similarly. Meek and Gray (1989) conclude that European firms with shares listed on the London Stock Exchange often exceed Exchange requirements through a wide range of voluntary disclosures, again with the expectation of lowering their cost of funds.

15 Representatives of ratings agencies, an international financial data service, and an organization working toward international accounting harmony were alsa interviewed. 
For the 52 institutions in our sample, a personal interview was conducted with representatives high enough in the management hierarchy to have decision responsibility. i.e. actually make international investment, funding, underwriting or regulatory decisions. He followed a written questionnaire covering factual and behavioral questions relating to decision processes, information requirements, nature of accounting diversity, coping mechanisms and capital market effects. All interview subjects were sent a sample of the interview questions in advance and some institutions prepared written answers ahead of time. All interview subjects were promised that there remarks would be kept confidential.

\section{Survey Findings}

The key question asked during our interviews was whether capital market decisions were affected by international accounting diversity. The results appear in Table 2 and show that approximately one-half of the respondents (24 of 50) feel that their capital market decisions are affected by accounting diversity. The hypothesis that accounting diversity has no affect must be rejected.

We then cross-tabulated the answers to this question against five descriptive categories - - nationality, size, extent of international investing/funding experience, scope of international investing/funding activities, and organization structure. These results appear in Table 3. We constructed a chi-square statistic to test for independence of "yes" and "No" responses within each category. In each case, we cannot reject the hypothesis that the "Yes" and "No" responses split proportionately regardless of country, size, experience, scope or organization structure. 16

Among underwriters, nearly all in our sample $(7$ of 8 ) feel that accounting diversity affects their capital market decisions. We suggest that this result stems from the function of underwriters as intermediaries tho deal with numerous issuers and investors; many of whom are not comfortable with national accounting differences. The sole underwriters who is not bothered by accounting diversity copes by (1) soliciting only top-tier firms in the industry, (2) relying heavily on credit ratings, and (3) using private placements to access foreign capital markets.

Among regulators, none that we interviewed reported being hindered by accounting

16 For the cross-tabulation of answers by "Size", we concluded that 'size' was not a relevant category for regulators. Excluding regulators results in a 24 "Yes" and 16 "No" split. 
diversity when approaching a capital market decision such as a listing or offering. Owing to their authority, regulators can cope with disclosure differences by requesting additional informetion. Even though most non-U.S. regulators analyze original source financial statements, our results show that they are not affected by accounting diversity. 17

The results for investors and issuers were more diverse and we consider them now in more detail.

Institutional investors. More than one-half ( 9 out of 17 ) of the investors in our sample stated that accounting differences make it more difficult for them to measure their decision variables, which ultimately affects their investment decisions. Respondents in this group tended to highlight the importance of accounting data and to point out the inadequacy of certain international accounting data for comparisons to a benchmark or for comparisons across countries. On the other hand, seven investors in our sample did not feel hindered by accounting differences. These respondents tended to focus on the economics of foreign investment opportunities, rely on local financial statements, utilize the services of local brokers or research houses, or adopt investment approaches that largely ignore accounting factors, such as the discounted dividend approach or a global portfolio allocation model. 18 Among the nine "Yes" and seven "No" investor response, we did not observe any correlation with either investor size, country of domicile, organization structure, length of experience in international investing, scope of international investments, or investment approach.

Among our sample of investors, Germany, Japan, and Switzerland were mentioned most frequently as troublesome countries for analysts when investing outside their home country. Across industries, 'banking and financial services, insurance, semi-conductors, and mining were identified as presenting analysts with similar difficulties. Specific differences in generally accepted accounting principles (GAAP) that are troublesome tc. investors relate to multinational consolidations, valuation of fixed assets, deferred taxes, pensions, marketable securities, discretionary reserves, foreign currency transactions and translations, leases, goodwill, depreciation, long-term construction contracts, inventory valuation and provisions. Similarly, the absence of comparable disclosure standards also hindered the analysis of about one-half

17 Non-U.S. regulators may cope in other ways, such as using sponsoring banks to validate they worthiness of a new listing or offering and to share in the liability of a poor decision.

18 The later approaches raise the question of whether these investors selected these approaches because they were unable to utilize accounting data prepared according to diverse principles. 
of the investors in our study. Disclosure items most frequently mentioned were segmental information, methods of asset valuation, foreign operations disclosures, frequency and completeness of interim information, description of capital expenditures, hidden reserves and off-balance sheet items.

All investors in our sample attempt to cope with accounting diversity in some fashion. For the nine investors who claim that accounting diversity represents a problem (the "Yes" group) seven cope by restating foreign accounts to a more familiar accounting framework. Two cope by adopting different investment strategies. One of these has elected to limit its foreign investments to govermment bonds and to equity investment in countries with accounting principles similar to its own. The second copes by utilizing a global portfolio allocation rule that abstracts from accounting information.

For the seven investors who respond that accounting diversity is not a problem that affects their capital market decisions, four cope by developing a multiple principles capability (MPC) -- undertaking to familiarize themselves with foreign accounting practices and to adopt a local perspective when analyzing foreign financial statements. The remaining three investors cope by relying on information less sensitive to corporate accounting treatment. One investor utilizes a dividend discount model, and another relies on macroeconomic variables for making asset allocations by country and then selects a diversified portfolio within each country. The final investor circumvents the problem of accounting diversity by relying primarily on "sociological trends" in making investment decisions. This involves first seeing in what direction consumer preferences are moving and then investing in industry leaders which are expected to capitalize on such trends.

Corporate issuers. Most of the issuers in our sample ( 9 out of 15) stated that accounting differences have no impact on their funding or listing decisions. The respondents in this group offered various explanations including funding strategies that insulate the company from reporting to foreign investors (such as internal funding or private placements), management's focus on economic fundamentals, management's confidence in investors' abilities to deal with account ing differences, and the value of "name recognition" in the capital markets that minimizes the need to focus on accounting considerations.

On the other hand, six issuers in our sample stated that accounting differences result in capital market effects. In some cases, accounting principles are the underlying cause. For example, the accounting treatment of intangibles left one of our respondents with a negative net worth, and unable to obtain a credit rating from a major agency and unwilling to attempt 
to raise funds in the United states. This firm turned instead to the European commercial paper market. More comon is the case of differences in disclosure requirements having an impect on funding and listing decisions, especially for firms domiciled in Japan and Germany. Disclosure items mentioned most frequently include preparation of consolidated statements, provision of information on business segments, reporting quarterly results, and explaining the nature of various reserves to foreign analysts.

Unl ike the case of investors, our responses from corporations reveal some distinct patterns. Firms who report that they are not offected by accounting differences tend to be from North America, are large in size, have had long experience in international financial markets, and have engaged in extensive international funding arrangements. Most North American firms are unaffected by accounting differences because they enjoy reciprocity when raising funds in foreign markets. Non-U.S. regulators generally respect the accounting principles of the issuer's home country while the United States requires restatement and reconciliation to U.S. GAAP and U.S.-style disclosure for public issues or listed securities.

Most corporations attempt to cope with accounting diversity. Several non-U.S. issuers cope by providing a full or portial restatement of their accounts to U.S. GAAP. However, this method is used selectively depending on whether the restatement casts the firm in a more or less fovorable light, and whether the restatement would provide privileged (and previously undisclosed) information to competitors. Two firms in our sample had issued ADR shares and were fortunate to be grandfathered from having to meet more stringent U.S. reporting requirements. Several firms cope by using road shows and hosting analysts meetings.

For the six firms that respond that accounting diversity (and the related regulatory diversity) affect their capital market decisions, coping behavior is very important. All six firms have avoided raising funds or listing their shares in the U.S. market and have relied on other means - - financing in the Eurobond market or the private placement market, domestic bank financing, offering sponsored but unlisted AORs in the United states, or simply encouraging foreign investors to buy the firms shares in their home market. For these six firms, accounting diversity clearly affected the geographic location of their funding and listing, and possibly affected their cost of capital. Several firms felt that their coping was highly effective in providing them with access to low cost funds. Other firms acknowledged that they had probably paid more to obtain external capital owing to their reluctance to disclose certain items that were viewed as proprietary, but that this was a price that they were willing to pay. 


\section{Conclusions and Imolications}

Our survey has revealed that many participants in the international capital markets - roughly $50 x$ in our sample -- believe that accounting differences are an important factor that affects their capital market decisions. 8y the same token, international accounting differences have existed for many years and coping behavior is widespread. Again, many participants in the international capital markets -- roughly $50 x$ in our sample $\cdots$ believe that their coping behavior has been successful and that their capital market decisions are unaffected. Which group dominates the capital markets and whether, at the margin, accounting diversity affects the pricing efficiency of markets remains an unanswered empirical question.

Nevertheless, our study has revealed several important patterns for institutional investors and corporate issuers. Investors in our sample who at tempt to cope by restating foreign accounting information report that accounting diversity affects their investment decisions. In other words, restatement is not sufficient to remove the problem of accounting diversity. This finding suggests that either (a) existing restatement algorithms are at a crude stage of development, (b) existing algorithms are not being applied effectively, or (c) no algorithm is capable of producing a proper and meaningful restatement. If the truth lies in (a) or (b) then more effort in restatement may result in a payoff. However if the true answer is (c), then investors may be right in developing their skills to read and interpret foreign financial statement in their original form.

In our sample, only four of 17 investors relied on original un-restated accounting information for their investment decisions (MPC'ers). Interestingly, but not surprisingly, none of these respondents reported that accounting diversity poses a problem as far as their investment decisions are concerned. Based on our survey, investors who make the effort to familiarize themselves with local enviromental norms anci develop skills in interpreting foreign accounts in their original form are least likely to encounter problems caused by accounting diversity.

Corporate issuers in our sample also revealed some distinct patterns. As could be expected, firm size and length of experience are associated with fewer problens relating to accounting diversity. Nationality also plays a role in explaining issuer behavior. U.S. and U.K. firms whose standards of accounting and financial disclosure tend to be relatively high appear to have greater flexibility in accessing international capital markets, while German, Japanese and Swiss firms whose financial statements are less transparent, e.g. in the areas of segmental disclosures and hidden reserves, appear to have less flexibility. This phenomenon 
may also be related to the asymetry between the United States (that provides a level playing field by demanding uni form accounting statements and uniform disclosures) and foreign countries (that practice reciprocity by accepting the accounting and reporting practices of the insur's mother country. The U.S. posture imposes additional costs on non-U.S. firms and some are not willing to bear these costs.

The differences in international funding and coping behavior can be understood if we take a broader view of the firm's cost of capital to include (1) financial costs, (2) information preparation costs, and (3) competitive costs. In communicating with foreign readers, firms can restate local GAAP statements into the account ing principles of the reader's country, supply additional disclosures, and/or have the audit report reflect an enhanced set of auditing standards. At the margin, additional information should lower the financial costs to the firm. But additional information is costly to prepare and may also increase the competitive costs to the firm. Thus the firm will provide the amount of information that optimizes the trade-off between competitive costs and financial costs.

This framework helps to explain why some firms are willing to restate to another set of GAAP rules but not disclose certain items of information, while others are willing to disclose more but unwilling to undertake GAAP restatements. This then ties into country of origin. Issuers fron a country with substantial accounting disclosure (e.g. the United Kingdom) tend to be more concerned about the impact of GAAP differences on their competitive costs. Issuers fron a country with limited disclosures (e.g. Germany and Japan) tend to be more concerned about the competitive costs of additional disclosure.

Finally, the positive correlation between length of international experience, frequency of exposure to international markets and the lesser importance attributed to accounting diversity as a decision problem highlights on: of the channels through which diversity may pose a barrier to capital market entry abroad. It also suggests that a key coping mechanism may simply be perseverance and the selective accomodation of investor information needs. If the investor's best coping mechanism is to be an MPC'er, then the issuer's best coping mechanism may be to help the investor to implement an MPC approach. 
Ball, R. "Changes in Account ing Techniques and Stock Prices," Empirical Research in Account ing. Selected Studies, 1972 (supplement), Journal of Accounting Research, 10 Spring 1972, p. 1-38.

Ball, R., and P. Brown. "The Empirical Evaluation of Accounting Income Numbers," Journal of Accounting Research, Autumn 1968, po. 159-177.

Block, Fischer. "International Capital Market Equilibrium with Investment Barriers," Journal of Financial Economics, December 1974

Branson, William H. and Dright M. Jaffe. "The Globalization of Information and Capital Mobility," working paper, Vincent C. Ross Institute of Accounting Research, New York University, September 15, 1989.

Choi, F.D.S. "Financial Disclosure and Entry to the European Capital Market," Journal of Account ing Research, Autum 1973, pp. 159-175.

Choi, Frederick D.S. and Richard M. Levich. The Capital Market Effects of International Account ing Diversity, Homewood, Ill inois: Dow Jones.Irwin, 1990.

Eun, Cheul and S. Janakiramanan. "A Model of International Asset Pricing with a Constraint on the Foreign Equity Ownership," Journal of Finance, 41, No.4, 1986, pp. 897-914.

French, Kenneth and James Poterba. "Are Japanese Stock Prices Too High?" manuscript, NBER Summer Institute, August 1989.

Gurwitz, Aaron S. "SEC RUle $144 \mathrm{~A}$ and Regulation S: Impact on Global Fixed Income Markets," Fixed Income Research Series, (New York: Goldman Sachs), September 1989.

Meek, G.K., and S.J. Gray. "Globalization of Stock markets and Foreign Listing Requirements: Voluntary Disclosures by Continental European Companies Listed on the London Stock Exchange," Journal of International Business studies, 20, No. 2 (Sumer 1989), pp. 315-36.

Russell, A., J.R. Grinyer, M. Walker, and P.A. Malton. Accounting for Goodwill, London: Certified Accountant Publications Limited, Research Report No. 13, June 1989.

Stapleton, Richard and Marti Subrahmanyam. "Market Imperfections, Capital Market Equilibrium and Corporate Finance," Journal of Finance, May 1977.

U.S. General Accounting office. International finance: Regulation of International Securities Markets, Washington, D.C.: GAO, April 1989. 
U.S. General Accounting Office. Foreign Investment: Country Differences in Accounting for Takeover Costs, Washington, D.C.: GAO, April 1987.

Watts, R.L. and J.L. Zimmermen. Positive Accounting Theory, Englewood Cliffs NJ: Prentice Holl, 1986.

World Bank. Emerging Stock Markets Factbook, Washington, D.C.: International Finance Corporation, 1989. 
Table 1

MATRIX OF INTERVIEH CANDIDATES

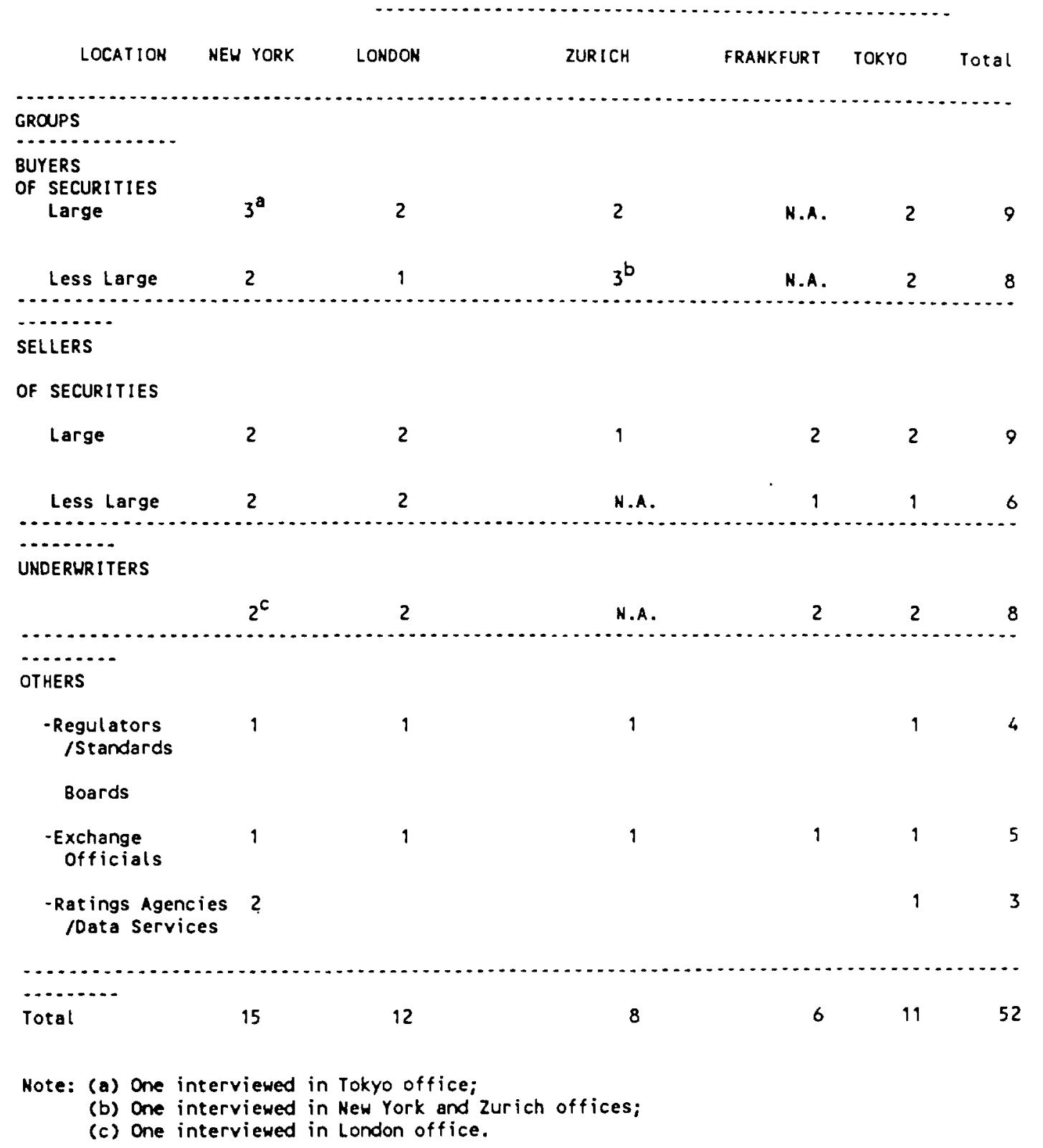


Table 2: Sumary Findings for Investors, Issuers, Underwriters, Regulators and Others

Key ouestion:

"Does accounting diversity affect your capital market decisions?"

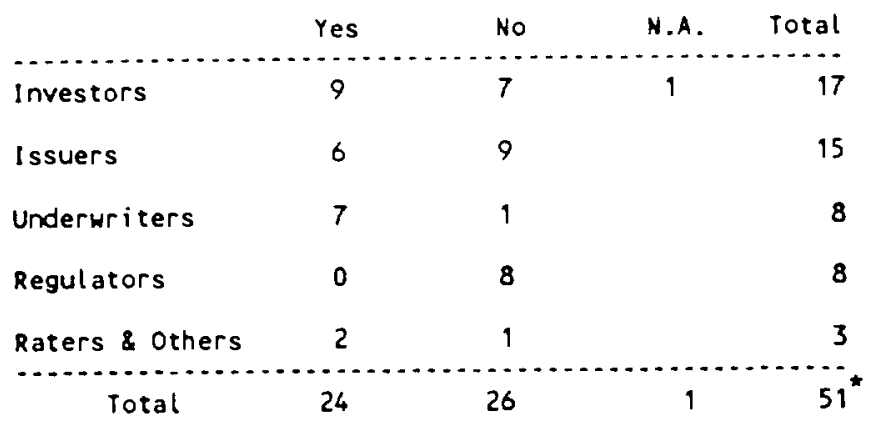

Note: The International Accounting Standards Comittee was interviewed but their answers are not included here. 
Table 3: Summary findings by Country, Size, Experience, Scope of Activity, and Organizational Structure.

Key Question:

"Does accounting diversity affect your capital market decisions?"

\begin{tabular}{|c|c|c|c|c|}
\hline Country & Yes & No & N.A. & Total \\
\hline $\begin{array}{l}\text { U.S. } \\
\text { Germany } \\
\text { Japan } \\
\text { Switzerl and } \\
\text { U.K. }\end{array}$ & $\begin{array}{l}6 \\
4 \\
6 \\
3 \\
5\end{array}$ & $\begin{array}{l}9 \\
2 \\
5 \\
5 \\
5\end{array}$ & 1 & $\begin{array}{r}15 \\
6 \\
11 \\
8 \\
11\end{array}$ \\
\hline Total & 24 & 26 & 1 & 51 \\
\hline Size & Yes & No & N.A. & Total \\
\hline$\ldots \ldots \ldots$ & $\ldots$ & $\cdots$ & $\cdots \cdots$ & $\ldots$ \\
\hline $\begin{array}{l}\text { Large } \\
\text { Less Large } \\
\text { N.A. }\end{array}$ & $\begin{array}{r}15 \\
9 \\
0\end{array}$ & $\begin{array}{r}12 \\
6 \\
8\end{array}$ & 1 & $\begin{array}{r}27 \\
16 \\
8\end{array}$ \\
\hline Total & 24 & 26 & 1 & 51 \\
\hline Experience & Yes & No & N.A. & Total \\
\hline $\begin{array}{l}\text { Long } \\
\text { Short } \\
\text { R.A. }\end{array}$ & $\begin{array}{r}14 \\
9 \\
1\end{array}$ & $\begin{array}{r}18 \\
8\end{array}$ & 1 & $\begin{array}{r}32 \\
18 \\
1\end{array}$ \\
\hline Total & 24 & 26 & 1 & 51 \\
\hline Scope & Yes & No & N.A. & Total \\
\hline $\begin{array}{l}\text { Limited } \\
\text { Extensive }\end{array}$ & $\begin{array}{r}9 \\
15\end{array}$ & $\begin{array}{l}12 \\
14\end{array}$ & 1 & $\begin{array}{l}22 \\
29\end{array}$ \\
\hline $\begin{array}{c}\text { Total } \\
\text { Tota }\end{array}$ & 24 & 26 & 1 & 51 \\
\hline Org. Structure & $\begin{array}{l}\text { Yes } \\
. . .\end{array}$ & No & N.A. & Total \\
\hline $\begin{array}{l}\text { Central ized } \\
\text { Decentralized } \\
\text { N.A. }\end{array}$ & $\begin{array}{r}13 \\
10 \\
1\end{array}$ & $\begin{array}{l}15 \\
11\end{array}$ & 1 & $\begin{array}{r}28 \\
22 \\
1\end{array}$ \\
\hline Total & 24 & 26 & 1 & 51 \\
\hline
\end{tabular}


Figure 1

Accounting Diversity and Economic Environments

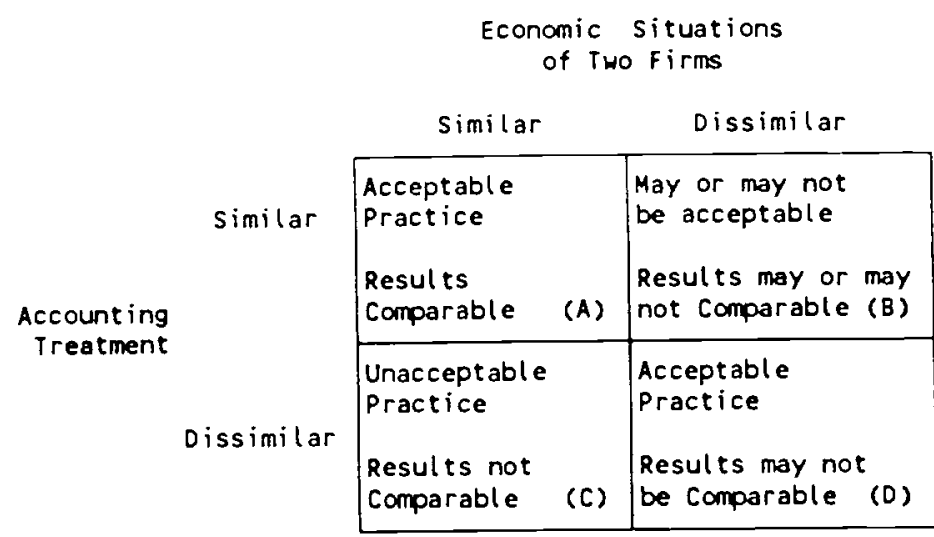

Note: The term "acceptable" is used here to mean appropriate or logical. 
APPENDIX 1

B.A.T. Industries, plc

Bank Julius Baer

Bear Stearns \& Co., Inc.

BHF-Bank

Brown Brothers Harriman \& Co.

Cadbury Schweppes, plc

Canon inc.

Capital Research Co.

Deutsche Bank

Exxon Corporation

Federation of German stock Exchanges

The Fuji Bank, Ltd.

General Electric Company

International Accounting Standards Board

Japan Ministry of Finance

Kleinwort Benson Ltd.

Lombard Odier \& Cie.

London Stock Exchange

Merrill Lynch Asset Management

The Mitsubishi Trust and Banking Corp.

Moody's Investors Service

Morgan Grenfell Group, plc

Morval \& Cie., S.A.

Nihon Keizai Shimbun Inc. (Data Bank Bureau)

Nestle, S.A.

New York Stock Exchange

Nippon Life Insurance Co.

Nissan Motor Company, Ltd.

Pfizer Inc.

Prudential-Bache

Prudential Portfolio Managers Limited

Reckitt \& Colman, plc

SANYO Electric'CO., Ltd.

Schering

Joseph E. Seagram \& Sons, inc.

Security Pacific Hoare Govett Ltd.

Siemens $A C$

Standard \& Poor's Ratings Group

Swiss Bank Corporation

Swiss National Bank

Teachers Insurance Annuity Association - College Retirement Equity Fund

Tokyo Stock Exchange

Union Bank of Switzerland

U.S. Securities and Exchange Cormision

Volkswagen $A G$

S.G. Warburg \& Co., Ltd.

WPP Group, plc

Yamaichi Securities Company

Yamaichi investment Trust Management

Zurich Stock Exchange

in addition, two organizations that wished to remain anonymous were interviewed. 